\title{
THE BENEFICIAL EFFECT OF FILTER-PRESS CAKE ON PINEAPPLE YIELDS UNDER FIELD CONDITIONS ${ }^{1}$
}

\section{E. Hernández-Medina, M. A. Lugo-López, and H. R .Cibes-Viadé2 INTRODUCTION}

In previous papers $(1,2,3)^{3}$ the influence of filter-press cake upon pineapple growth, development, and production has been discussed. The results from pot experiments comprising a plant-crop and first-ratoon-crop cycle indicated that pineapple plants grown in soil with the top 6 inches of which filter-press cake had been mixed, developed more vigorously and were of a darker green color, their leaves were wider and their stem and flower stalks thicker than those of pineapple plants treated otherwise. Furthermore, they were the heaviest fruit yielders, and were superior in slip and sucker production.

These encouraging preliminary results from pot experiments at Río Piedras suggested the possibility of using filter-press cake as a soil amendment in pineapple fields, in conjunction with fertilizers, so as to increase yields of pineapple, low yields being a limiting factor to pineapple-growing in Puerto Rico. They further led to additional work to test the possibility of successfully reproducing under field conditions the results obtained in pots.

This paper reports the results obtained from two field experiments established in representative pineapple-growing areas of the Island. Different rates of filter-press cake were applied at both sites to determine the minimum application required for maximum crop yields at each site. Two levels of fertilizer were also tested at both locations in combination with various quantities of filter-press cake.

\section{MATERIALS AND MLTHODS}

Two fields were selected, one at Palo Blanc'o, Arecibo, in northern Puerto Rico, and one at the farm of the Corozal Agricultural Experiment Substation in the interior. At Arecibo the soil had been classified as Bayamón silty clay, an acid, deep, lateritic soil of the coastal plain derived from

1 This paper constitutes the third in a series on the same general subject, the first and second of which will be found in the Journal of Agriculture 36 (3) 255-301 1952.

2 Assistant Plant Physiologist, Associate Soil Scientist, and Associate Plant Physiologist, respectively, Agricultural Experiment Station, University of Puerto Rico, Río Piedras, P. R. Appreciation is expressed to H. Gandía and R. Olivencia for their help in connection with the field experiment at Corozal. Thanks are due also to Enrique Landrón who provided land, labor, and other facilities for the Palo Blanco Experiment.

${ }^{3}$ Numbers in parentheses refer to Literature Cited, p. 212. 
limestone. At Corozal, the soil is a typical, nearly level, medium-friable Lares clay occurring in terrace formations and derived from material washed from the lower Tertiary clays and shales.

Plots of $20 \times 8$ feet, comprising an area of $1 / 272$ of an acre, were found to be most adequate for the field work. On each plot 3 rows of pineapples were planted, 15 plants to the row. At this rate a total of 12,240 plants would be required to plant an acre of pineapple. Slips of the Red Spanish variety, the commercial pineapple of the Island, were planted on September

TABLE 1.-Soil treatments used for pineapple growing at the experimental fields in Arecibo and Corozal

\begin{tabular}{|c|c|c|c|}
\hline \multirow{3}{*}{$\begin{array}{l}\text { Treatment } \\
\text { identification } \\
\text { letter }\end{array}$} & \multicolumn{3}{|c|}{ Description of soil treatments ${ }^{1}$} \\
\hline & \multirow{2}{*}{$\begin{array}{c}\text { Filter-press } \\
\text { cake applied } \\
\text { per A. }\end{array}$} & \multicolumn{2}{|l|}{ Fertilizer used } \\
\hline & & Amount and analyses & Application \\
\hline & Tons & & Number \\
\hline $\mathrm{A}$ & 8 & 1,500 lbs. of $12-6-10$ & 3 \\
\hline $\mathrm{B}$ & 16 & 1,500 lbs. of $12-6-10$ & 3 \\
\hline $\mathrm{C}$ & 24 & $1,500 \mathrm{lbs}$. of $12-6-10$ & 3 \\
\hline $\mathrm{D}$ & 32 & $1,500 \mathrm{lbs}$. of $12-6-10$ & 3 \\
\hline $\mathrm{E}$ & 32 & $1,500 \mathrm{lbs}$. of $12-6-10$ & 1 \\
\hline $\mathrm{F}$ & 32 & $3,000 \mathrm{lbs}$. of $12-6-10$ & 4 \\
\hline $\mathrm{G}$ & 32 & 3,000 lbs. of $12-6-10$ & 4 \\
\hline $\mathrm{H}$ & 32 & 0 & - \\
\hline I & 32 & 360 lbs. $\mathrm{NH}_{3}+180$ lbs. $\mathrm{P}_{2} \mathrm{O}_{5}$ & 4 \\
\hline $\bar{J}$ & 32 & 180 lbs. $\mathrm{P}_{2} \mathrm{O}_{5}+240$ lbs. $\mathrm{K}_{2} \mathrm{O}$ & 4 \\
\hline $\mathrm{K}$ & 32 & 360 lbs. $\mathrm{NH}_{3}+240$ lbs. $\mathrm{K}_{2} \mathrm{O}$ & 4 \\
\hline $\mathrm{L}$ & 0 & 3,000 lbs. of $12-6-10$ & 4 \\
\hline $\mathrm{M}$ & 0 & 3,000 lbs. of $12-6-10+\operatorname{lime}^{2}$ & 4 \\
\hline
\end{tabular}

${ }^{1}$ In all treatments except in $\mathrm{F}$ and $\mathrm{L}, 2$ iron sprays were used on the plants, as is customary in commercial pineapple cultivation.

${ }^{2}$ Soil limed with calcium carbonate to raise $\mathrm{pH}$ up to 6.5 .

18 and 25, 1950, at Corozal and Arecibo, respectively. Fertilizer applications as shown in table 1, were made at both locations in October 1950, and during January and May of the following year. Iron sprays were used where required (table 1), towards the end of December 1950 and again in the following March.

Thirteen treatments were tested at both fields, each replicated eight times in an incomplete-block design. A detailed record of the treatments used can be found in table 1 . The filter-press cake was 3 months old at the time of application and contained about 70-percent moisture. It was worked into the top 4 to 6 inches of soil prior to planting the pineapple slips.

To induce flowering, the plants from both experiments were treated with 
acetylene approximately 1 year after being planted. This consisted of spraying the crown of the plant with 25 or $30 \mathrm{ml}$. of a solution made by dispersing 2 ounces of calcium carbide in 5 gallons of water in a closed container.

In April 1952, when the plants were about 18 months old, the fruits were harvested as is usual in commercial pineapple fields. The criteria used in evaluating the effect of the treatments were the weight and amount of marketable fruits, the mean production per acre, and the slip production per plant. All data on weight of fruit, yield per acre, and slip production were statistically analyzed.

\section{RESULTS AND DISCUSSION}

Data on mean weight of fruit, mean yield per acre, and slip production per plant are given in table 2 for the Arecibo experiment. A study of the data reveals that larger fruits were obtained from plots receiving filterpress cake at the rate of 32 tons to the acre (treatment D) than from plots receiving lesser amounts, when the fertilizer application was at the rate of only 1,500 pounds to the acre (treatments A and B). Furthermore, significantly heavier yields were obtained from plots receiving filter-press cake at the rate of 32 tons to the acre than from those receiving it at rates of only 8 and 16 tons (treatments A and B). Complete omission of the fertilizer (treatment $\mathrm{H}$ ) led to highly significant reductions in yield and weight of fruit, even when the same quantities of filter-press cake were used (treatments F and G). When nitrogen was omitted from the fertilizer (treatment J), both the mean weight of the fruit and the total production of fruit were markedly reduced. Omissions of either potash (treatment I) or phosphoric acid (treatment $\mathrm{K}$ ) did not significantly reduce yields. The use of fertilizers at the rate of 3,000 pounds to the acre (treatment $\mathrm{L}$ ) resulted in high yields even though no filter-press cake was applied. However, liming the soil to $\mathrm{pH} 6.5$ (treatment $\mathrm{M}$ ) affected the production of fruit adversely. At this location the use of 32 tons of filter-press cake per acre, in conjunction with 1,500 pounds of fertilizer proved sufficient for maximum yields. The use of 360 pounds of $\mathrm{NH}_{3}$ in addition to 32 tons of filter-press cake per acre would perhaps also be sufficient.

Whether the fertilizer was applied all at once or split in three or four applications had no effect on the final yields and weights of fruits. Spraying with ferrous sulfate was not effective either.

Thus, it seems that, in this area, when at least 32 tons of filter-press cake are applied to the acre, there is no need to apply more than half the fertilizer that is usually used in pineapple fields. When only half of the fertilizer generally used was applied, the plants from the plots which received applications of filter-press cake at the rate of 32 tons (treatments D and E) to the acre produced more slips than those which received 8 tons (treatment A) of filter-press cake to the acre. Omissions of nitrogen (treatment 
J) from the fertilizer or of filter-press cake (treatments L and M) resulted in a significant reduction of the slips produced per plant.

Table 3 shows the mean weight of fruits and mean yields of fruit to the acre for the Corozal experiment. The results from this experiment further confirm some of the conclusions obtained from the Arecibo experiment. There was, however, a marked response to potash, as well as to nitrogen,

TABLE 2.-Mean fruit weight, pineapple yield per acre, and slip production per plant at the filter-press-cake experimental field, Palo Blanco, Arecibo

\begin{tabular}{c|c|c|c}
\hline $\begin{array}{c}\text { Treatment } \\
\text { identification letter }\end{array}$ & Mean weight of fruit & Mean yield of fruit per acre & Mean slips per plant \\
\cline { 2 - 4 } & Pounds & Tons & Number \\
A & 2.92 & 17.87 & 3.3 \\
B & 3.00 & 18.36 & 3.7 \\
C & 3.22 & 19.71 & 3.8 \\
D & 3.38 & 20.69 & 4.2 \\
E & 3.24 & 19.83 & 4.6 \\
F & 3.51 & 21.48 & 5.1 \\
G & 3.47 & 21.14 & 4.7 \\
H & 2.82 & 17.26 & 3.8 \\
I & 3.40 & 20.81 & 4.6 \\
J & 3.06 & 18.73 & 3.9 \\
K & 3.41 & 20.87 & 5.0 \\
L & 3.32 & 20.32 & 3.9 \\
M & 2.99 & 18.30 & 3.4 \\
\hline
\end{tabular}

L.S.D. between mean weight of fruit at the:

5 -percent level

0.32 pounds

1 -percent level.

.42 pounds

L.S.D. between mean yield of fruit per acre at the:

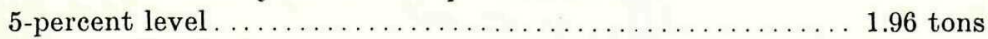

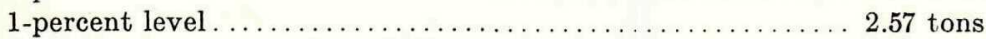

L.S.D. between mean number of slips at the:

5 -percent level.

1-percent level.

1.2 slip

in this experiment. The omission of either one of these elements resulted in a decrease of about 3 tons of pineapple to the acre (see table 3 and compare treatments I and $\mathrm{J}$ with $\mathrm{F}, \mathrm{G}$, and $\mathrm{K}$ ) even at the highest level of filter-press cake.

The soils of the Lares series of Corozal are unable to supply enough available potash for a crop of pineapples. In the Bayamón soils of the Arecibo coastal plains the omission of potash was not detrimental to pineapple production when 32 tons of filter-press cake were applied in addition to inorganic nitrogen and phosphorus. The pineapples from plots not receiving filter-press cake, (treatments $\mathrm{L}$ and $\mathrm{M}$ ) even though they received 
a complete fertilizer application of 3,000 pounds on the acre basis, produced the smallest fruits and the lowest total yields to the acre. In the Corozal and other areas having similar soil conditions the necessity for making large applications of fertilizer, such as the 3,000 pounds to the acre of a 12-6-10 fertilizer used in these experiments, is rather marked, even when filter-press cake is used at a rate of 32 tons to the acre. (Compare treatments $\mathrm{F}$ and $\mathrm{G}$ with mean of treatments $\mathrm{D}$ and $\mathrm{E}$ ). In other words,

TABLE 3.-Mean fruit weight and yield per acre of pineapples grown at the filter-press cake experimental field, Corozal Substation Farm

\begin{tabular}{c|c|c} 
Treatment identification letter & Mean weight of fruit & Mean yield of fruit per acre \\
\cline { 3 - 3 } A & Pounds & Tons \\
B & 2.64 & 16.16 \\
C & 2.78 & 16.98 \\
D & 2.89 & 17.71 \\
E & 2.96 & 18.08 \\
F & 2.79 & 17.07 \\
G & 3.23 & 19.76 \\
H & 3.44 & 21.03 \\
I & 2.64 & 16.17 \\
J & 2.76 & 16.90 \\
K & 2.71 & 16.61 \\
L & 3.25 & 19.86 \\
M & 2.36 & 14.42 \\
\end{tabular}

L.S.D. between mean weight of fruit at the:

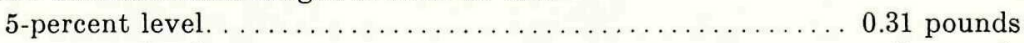

1 -percent level. .............................42 pounds

L.S.D. between mean yield of fruit per acre at the:

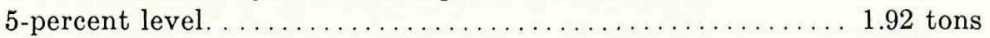

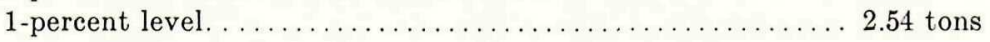

both heavy fertilization and heavy applications of filter-press cake are required for maximum yields. However, applications of 32 tons of filter-press cake with only 1,500 pounds of fertilizer will produce significantly higher yields and heavier fruits than applications of twice as much fertilizer if filter-press cake is omitted. (Compare treatment $\mathrm{D}$ with treatments $\mathrm{L}$ and $\mathrm{M})$.

In Arecibo and related areas considerable savings can be made by the farmers without decreasing yields, because filter-press cake can be obtained free from most sugar mills and hauled to the farm at a relatively low cost. Furthermore, the Production and Marketing Administration makes benefit payments to farmers of $\$ 1^{4}$ per ton of filter-press cake applied. These pay-

${ }^{4}$ Only 50 cents for sugarcane farmers, but $\$ 1$ for all others. 
ments, in addition to increasing the farmers' gross income, are a rather strong incentive to continuous and more widespread use of filter-press cake and, consequently, will help to restore and maintain an adequate level of organic matter in the soil. Details on the possible effects of the filter-press cake upon soil conditions are presented in a second article in this issue of the Journal of Agriculture.

\section{DISCUSSION}

It is of interest to point out that, throughout their growth period, the pineapple plants which developed in soil previously treated with filter-press cake at both locations were always superior in vigor, the leaves were greener in color, they were taller, and their stems and flower stalks were thicker than those of pineapple plants given other treatments.

- Field work with filter-press cake will necessarily be expanded. The two field experiments at Arecibo and Corozal will be continued to complete the crop cycle. Meanwhile, the results herein reported for the plant crop provide rather important reference points as to what may be expected from filter-press cake applications to pineapple fields.

The economic implications of applying only half of the fertilizer generally used, when filter-press cake is available, can be far reaching in areas where conditions similar to those around Arecibo prevail. About the same bulk of pineapple can be produced much cheaper by using 1,500 pounds of fertilizer and filter-press cake than when 3,000 pounds to the acre of fertilizer are used. In other places, such as the Corozal region, high levels of both filter-press cake ( 32 tons to the acre) and fertilizer (3,000 pounds to the acre) are necessary for maximum yields. Nitrogen is a limiting factor for pineapple production in Arecibo while both nitrogen and potash are limiting factors at Corozal.

\section{SUMMARY}

Data from two field experiments located in typical pineapple growing areas in the northern and interior regions of Puerto Rico are reported here. Pineapple plants grown in soil to which filter-press cake was applied previous to planting developed vigorously and were of a dark-green color. Their leaves were wider and their stems and flower stalks thicker than those of pineapple plants given other treatments.

At one location, Arecibo, pineapple plants grown in soil receiving at least 32 tons of filter-press cake to the acre, in addition to 1,500 pounds of a 12-6-10 fertilizer, produced yields as high and fruits as large as plants grown in soil receiving twice as much fertilizer but no filter-press cake. Omissions of nitrogen or filter-press cake resulted in reduced yields.

The possibility of using filter-press cake more extensively in pineapple fields in the Arecibo and related areas, in conjunction with smaller doses 
of fertilizers than are generally used, deserve careful consideration from the growers.

At the second location, Corozal, 3,000 pounds of fertilizer in addition to 32 tons of filter-press cake to the acre proved to be necessary for maximum yields. Omissions of both potash and nitrogen are detrimental to pineapple production.

\section{RESUMEN}

Se presentan aquí datos de dos experimentos sobre abonamiento de la piña llevados a cabo en áreas representativas en el Norte y en el Interior de la Isla. Cuando se trató el suelo con cachaza, las plantas de piña se desarrollaron vigorosamente y tuvieron un color verde oscuro. Las hojas fueron más anchas y los tallos y pedúnculos florales más gruesos que los de las plantas que se desarrollaron en las parcelas sometidas a otros tratamientos.

En la zona de Arecibo, en el suelo que recibió no menos de 32 toneladas de cachaza por acre, además de 1,500 libras de un abono 12-6-10, las plantas de piña produjeron rendimientos tan altos y frutas del mismo tamaño que aquellas que se desarrollaron en el suelo, al cual se le había aplicado el doble de la cantidad de abono antes mencionada, pero donde se había omitido la cachaza. Cuando se omitió el nitrógeno del abono, o no se aplicó la cachaza, se redujeron los rendimientos.

Los resultados de estos experimentos señalan la posibilidad de usar más ventajosa y extensivamente la cachaza, conjuntamente con menores cantidades de abono que las que se usan ahora en los plantíos de piña de la zona de Arecibo. En la zona de Corozal se necesitan 3,000 libras de abono, además de 32 toneladas de cachaza por acre de piña para poder obtener los rendimientos máximos de esta cosecha. La omisión de la potasa y la del nitrógeno en los abonos para piña perjudica los rendimientos.

\section{LITERATURE CITED}

1. Hernández-Medina, E., The beneficial effect of filter-press cake on pineapple growth, development, and production: I. Effect on the plant crop. J. Agr. Univ. P. R. 36 (3) 255-80 1952.

2. Hernández-Medina, E., The beneficial effect of filter-press cake on pineapple growth, development, and production: II. Effect on the ratoon crop. J. Agr. Univ. P. R. 36 (3) 281-301 1952.

3. Hernández-Medina, E., Filter-press cake increases pineapple yields in Puerto Rico, Univ. of P. R. Agr. Exp. Sta. Bull. 1041952. 